\title{
AS MALSUCEDIDAS BUSCAS DE MINERAIS EM MINAS GERAIS
}

\author{
Luciano E. Faria ${ }^{\mathrm{a}, *,()}$ e Carlos Alberto L. Filgueiras ${ }^{\mathrm{b}}$ \\ ${ }^{a}$ MMGerdau - Museu das Minas e Metais, Praça da Liberdade s/n., Funcionários, 30140-010 Belo Horizonte - MG, Brasil

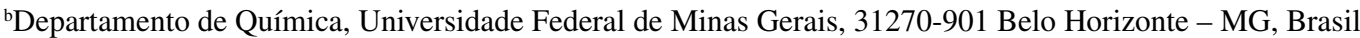

Recebido em 23/08/2021; aceito em 03/11/2021; publicado na web em 30/11/2021

\begin{abstract}
THE UNSUCCESSFUL MINERALS SEARCH IN MINAS GERAIS. After extracting practically all the gold and diamonds from the captaincy of Minas Gerais, Brazilian and foreign politicians and naturalists were looking for new sources of wealth in the form of ores. However, the news of the discovery of copper and cobalt mineral deposits, made by José Vieira Couto (a naturalist from the city of Diamantina), were discredited because the locations indicated or even the analysis performed may have been done incorrectly or even intentionally altered by the naturalist in order to draw the attention of the Portuguese Crown or seeking ways of obtaining social and political promotion among the colony's governors.
\end{abstract}

Keywords: copper; cobalt; chemical analisys.

\section{“NEM TUDO O QUE RELUZ É OURO"}

Desde o início do século XIX até o século XX, boa parte daquilo que se destacava nos informes sobre novas descobertas de minerais em Minas Gerais, ou da possibilidade de extração de novos minérios, parece não ter surtido efeitos práticos ou econômicos. Neste artigo serão narrados alguns casos em que fraudes, ufanismo, a pouca quantidade de veios ou até mesmo eventuais erros de análises da composição mineral, malograram a tentativa de se obter cobre e cobalto. A busca por novas fontes de riqueza era prioridade no governo, ora da capitania, ora da província de Minas Gerais, que experimentava uma enorme diminuição na produção de bens naturais antes tão abundantes como o ouro e os diamantes, que minerados no século XVIII foram imensas fontes de riquezas ao Reino de Portugal.

O cobre foi um dos principais responsáveis pela evolução das tecnologias humanas que envolveram, no passado, a mineração e a metalurgia e que fizeram parte da cultura de certos povos entre 7 a 10 mil anos atrás. ${ }^{1,2}$ Devido ao fato de ter sido trabalhado em sua forma nativa, em ligas naturais e em minérios, diversos instrumentos de cobre ou de suas ligas artificiais ainda são achados em países do Oriente Médio e Europa, assim como nos Andes, demarcando um longo espaço temporal determinado como "a Idade do Bronze". Nos dias de hoje, as características específicas do cobre conferem a este metal uma grande diversidade de aplicações que continuam estimulando o avanço tecnológico e fazendo com que reservas minerais de cobre sejam muito prospectadas. ${ }^{3}$

O Brasil não é um dos maiores produtores mundiais de cobre e a produção deste metal em nosso país é capaz de suprir apenas a metade da necessidade do metal para as diversas aplicações nas quais ele é utilizado. No entanto, a produção de seu minério (com um teor médio de $0,61 \%$ em massa) nos estados do Pará, Goiás e Bahia somaram em 2016 um total de 89,7Mt. ${ }^{4}$ Apesar de escasso no Brasil, o cobre foi o metal que primeiro chamou a atenção dos exploradores portugueses que, ao navegarem nas regiões mais austrais do Brasil, perceberam que os gentios - forma como denominavam os indígenas - utilizavam em forma de adornos e armas certas peças metálicas compostas de cobre, conforme se constata no título da comunicação feita em 1619:

\footnotetext{
*e-mail: luemfa@hotmail.com
}

\begin{abstract}
Carta do [fidalgo] Martim de Sá ao rei [D. Filipe II] ... informando que não pôde ajudar seu pai na busca das minas, que teve conhecimento das minas de cobre, que fez. descer o gentio, fundou aldeias e tratou das pazes, enviando amostras de murão e cobre do Rio Grande que o gentio usa para armas; solicitando regimento e ordens sobre o que fazer com os impedimentos impostos pelo governador e capitãomor do Rio de Janeiro, Rui Vaz Pinto, no cumprimento do seu cargo de superintendente das coisas de guerra na costa do sul. Lisboa, 7 de Abril de 1619.5
\end{abstract}

Ainda no século XVII, a necessidade pela fabricação de grandes tachos e caldeiras de cobre para serem utilizados na crescente monocultura da cana-de-açúcar, utilizados para isolar e purificar seu doce componente, fazia da importação deste metal um dos itens mais caros ao desenvolvimento da produção do açúcar na colônia. Esse pode ter sido o principal motivo a estimular a busca do cobre nativo ou de seus minérios no interior das capitanias do Nordeste, até culminar, no fim do século XVIII, em um dos capítulos mais interessantes sobre esse metal no nosso país, fato que é amplamente discutido pela pesquisadora portuguesa Maria Estela Guedes em seu blogue-revista "Triplo V". ${ }^{6}$ Em 1782 os rumores da descoberta de um imenso bloco de cobre na Capitania da Bahia, nas proximidades do termo da Vila da Cachoeira aguçaram os interesses do governo e de naturalistas de Portugal a empenharem pesquisas minerais nos sertões brasileiros. Após ter sido enviado a Portugal, o enorme objeto natural (as massas apontadas pelos naturalistas variavam de 450 a $1.740 \mathrm{~kg})^{6}$ foi sujeito a diversas análises que apresentaram discordâncias sobre qual era a massa real daquele e a composição da liga. Divergências mais atuais questionam a origem do bloco de cobre que, geologicamente, não pode ter sido encontrado no Recôncavo Baiano, como indicavam os descobridores, uma vez que nessa região não existem minerais de cobre e nem mesmo marcas de astroblemas (crateras formadas pela queda de corpos celestes como meteoritos). Dessa forma, Guedes concluiu que o bloco teria funcionado "como chamariz para obrigar o Poder a enviar naturalistas para as colónias - no lugar onde aparecera uma pepita tão grande, por força tinham de existir minas fabulosas". ${ }^{7}$ Esse é um dos mais notáveis casos ocorridos no Brasil em que alguém tenha tentado "salgar a amostra", de acordo com expressão utilizada pelos geólogos sobre a tentativa de atrair a atenção para a exploração mineral em uma localidade por meio do 
acréscimo fraudulento de itens minerais. Por outro lado, uma série de documentos históricos indicam a descoberta de minerais de cobre no interior das capitanias nordestinas de Pernambuco (em Piancó, hoje estado da Paraíba) ${ }^{8}$ e Bahia (em Curaçá, na Serra da Borracha). ${ }^{9-11}$

$\mathrm{O}$ grande interesse português na busca de novas fontes de cobre, nativo ou em minério, deve ter se intensificado no Brasil uma vez que a Inglaterra era responsável por três quartos da produção mundial de cobre no século XVIII, em um monopólio que durou até os meados do século XIX. ${ }^{12}$ Além disso, a Grã-Bretanha proibiu "na última década do século XVIII a exportação de cobre para fora dos seus domínios e colocou Portugal em dificuldade para obter a quantidade de metal indispensável à cunhagem de sua moeda fiduciária". ${ }^{13}$

\section{O COBRE EM MINAS GERAIS}

É durante este período crítico que uma das primeiras referências sobre a existência de cobre em Minas Gerais foi feita em carta pelo governador da Capitania, Luís António Furtado de Castro do Rio de Mendonça e Faro - o Visconde de Barbacena - a seu tio, o então Vice-rei do Brasil D. Luís de Vasconcelos e Souza, pouco mais de um ano após sua chegada no Brasil em 1788. A carta, cujo conteúdo é reproduzido nos Autos da Devassa ${ }^{14}$ indica a boa relação com o também recém-chegado Doutor em Filosofia Natural pela Universidade de Coimbra, o chymico José Álvares Maciel. ${ }^{15}$ Este último, habitando as dependências do palácio do Visconde, em Cachoeira do Campo, trabalhou

Desde certo tempo, na indagação de minas (especialmente de cobre e de ferro, que ensaia repetidas vezes, por sua curiosidade e até com despesa própria), e anda com grande desejo de salitre, de forma que, se as minhas ocupações me não tivessem afastado deste gênero de aplicação, teria ele já fundido em grande e adiantado muito mais os seus conhecimentos nesta parte. ${ }^{14}$

Pelo papel que desempenhou na Inconfidência Mineira, desde sua chegada ao Brasil, Maciel foi mais tarde indiciado por traição pelo próprio Visconde de Barbacena e por isso é sentenciado à prisão perpétua e enviado para a colônia portuguesa de Angola. É dessa colônia na África que Álvares Maciel sempre volta sua atenção e pensamento "ao passado, para os entes de sua estima, que deixara muito longe, muito além do Oceano, procura Alvares Maciel, por vêzes, se tornar útil à terra do seu nascimento". ${ }^{16} \mathrm{O}$ químico $\mathrm{e}$ inconfidente descreve seus trabalhos de prospecção mineral em Minas Gerais ao Governador de Angola, D. Miguel Antônio de Mello, que anuncia tal descoberta em uma carta enviada ao então governador da Capitania de Minas Gerais no ano de 1799, Bernardo José de Lorena (que havia substituído o Visconde de Barbacena, no governo de Minas Gerais). A carta, cuja cópia se encontra no Arquivo Público Mineiro, ${ }^{17}$ descreve a descoberta de Maciel que teria acontecido em datas anteriores à sua viagem até Angola na sua estadia em Minas Gerais entre 1788 até 1789 :

Cópia do § de huma carta do Governador de Angola D. Miguel Antônio de Mello com data de 19 de Setembro de 1799 debaixo do N. $105^{\circ}$. O digníssimo Governador actual da Capitania de Minas Gerais certamente terá dado a V. Exa . notícia das Riquezas que ali existem, mas por que espero V. Ex ${ }^{a}$. desculpe a liberdade, que tomo de lhe participar o que sei, tenho a honra de dizer a V. Ex ${ }^{a}$., que Jozé Álvares Maciel me certificou ter descoberto em Villa Rica nas fraldas da Saramenha junto ao Rio, que ali passa no Districto da Frequezia de Antônio Dias, Vitriolo de Cobre, o qual corre d'entre hum Banco de squisto, e nos tempos de seca costuma cristalizar-se. Que no mesmo sitio achou uma Argila Nicacia semelhante á Mica, e de cor verde, que exposta ao fogo perde em breve espasso a cor, e se liquida como vidro. Que no Morro das Lages há abundancia de Arsenico, de Oiro Pimenta, e de Ferro, e na Mina chamada Contijo Enxofre. E finalmente que desde a Cachoeira do Campo até S. João do Morro Vermelho há hum banco de Pedras aggregadas, que tem uma braça de largo, e outra de alto, no qual descobrio grande riqueza de cobre puro"

O rio descrito deve se tratar do Rio do Carmo que passa pelo atual distrito industrial de Saramenha, e fica na porção sudoeste de Ouro Preto. Nesse local, Maciel deve ter descoberto o vitríolo (ou sulfato) de cobre o que leva a crer tratar-se do raro mineral calcocianita que se cristaliza em formato ortorrômbico quando se encontra em sua forma anidra. Já a formação do banco de pedras que indica existir "desde Cachoeira do Campo até S. João do Morro Vermelho" pode indicar o delineamento entre o distrito ouro-pretano de Cachoeira de Campo até o distrito de Morro Vermelho, da cidade de Caeté. Essa linha em sentido sul-norte se estende entre os distritos por mais de $50 \mathrm{~km}$, passando pela Serra do Gandarela, cujas formações ferríferas são abundantes em cangas - conglomerados de seixos que podem ser descritos como bancos de pedras conforme descreve Maciel.

A narrativa parece ter obtido a atenção de Bernardo de Lorena que, dois anos após o envio da carta de Angola, remete a D. Rodrigo de Souza Coutinho um "pequeno caixote" com o resultado da coleta de minerais feita pelo irmão de José Álvares Maciel, Domingos Alves de Oliveira Maciel. Pelo interessante conteúdo do documento anterior, datado de 1801 e que se refere ainda a outro grande naturalista, já retratado em artigos já publicados, o tijucano e doutor José Vieira Couto, optou-se por trazer neste texto a carta completa de Lorena: ${ }^{18,19}$

Carta ( $2^{a}$ via) de Bernardo José de Lorena, governador das Minas, para D. Rodrigo de Sousa Coutinho, enviando "o pequeno caixote" com amostras mineralógicas e carta de Domingos Alves de Oliveira Maciel, irmão de José Alves de Oliveira Maciel. Informa que é grande a quantidade de cobre descoberto por José Vieira Couto.

N. 6. $\mathrm{Ill}^{\mathrm{mo}}$ e Ex $\mathrm{x}^{\mathrm{mo}} \mathrm{Snr}$

Em consequencia do officio de V. Ex . N 23 do anno passado, remeto o pequeno caixote, com a Participação de Domingos Alves de Oliveira Maciel, Irmão do $D^{o r}$. José Alves de Oliveira Maciel. He tão grande a abundancia de cobre descuberto pelo Doutor Couto, que parecem escuzados mais indagaçõens sobre semelhante objecto: e eis aqui quanto posso dizer a $V$. Ex $x^{a}$. para ser presente ao Principe Regente Nosso Senhor. $D^{s} . G^{e} . a V . E x^{a}$.

Villa Rica, 04 de Fevereiro de 1801.

$I l l^{m o}$. e Ex ${ }^{m o}$. Snr. D. Rodrigo de Souza Coutinho Bernardo José de Lorena.

Copia

$I l l^{m o}$. e Ex $x^{m o}$. Snr.: Meu Senhor. O resultado das operaçoens chimicas, que tenho a honra de aprezentar a V. Excellencia, he quanto basta, segundo me parece, para testimunhar a minha prompta, e cega obediencia em satisfação do que V. Excellencia me imcumbio, fazendo somente ver a existencia das Minas anunciadas por meu Irmão o $D^{o r}$. Jozé Alvares Maciel, do Ex ${ }^{m o}$. Snr. D. Miguel Antonio de Mello, sem fixar porem com exactidão de hum rigoroso calculo, para o qual me seria precizo a providencia de vazos próprios, que se não achão neste Paiz, e a construção de Fornalhas regulares, que omiti pella brevidade do tempo. 
Entre os cítios apontados he o Morro do Saramenha, Freguezia de Antônio Dias em qual achei a rica Mina de Pirites de Cobre, que se ve na caixa, que ofereço em o Numero 1 muito digna de ser notada, tanto pello que em se contem, como por ser um filão de muita largura, e de muito fácil extracção: dela tirei o Enxofre, que se vê na mesma Caixa em a $N^{o}$. $2^{\circ}$. e o Cobre $N^{o}$. 3. Junto deste segue a Mina de Vitriolo, que aprezento em o N. 4. Da qual extrahi $o$ Vitriolo, que se ve em a N. 5. Passando depois a Mina denominada do Contijo, $q$ é cituada no Morro das Lages desta mesma Villa achei a Pirites Arsenical, que se ve em o N. 6. da qual em pequena quantidade extrahi em abundancia o Arsenico amarelo, e o pó, ou farinha Arsenical, de que se vem as amostras nos Vidros N. 7. e além de ser um filão de três pes de largura em partes se faz ainda mais apreciavel pella quantidade de Cobalto, que contem. E como todo este Morro não admita outros trabalhos para a extracção do Ouro, senão das Minas Subterrâneas, me asseverão alguns dos activos Mineiros q nestas aparecem Varias Substancias Minerais muito recomendáveis pella sua figura, e pezo, $e$ outras mesmo pelo seu saber, e ter, mais esta exploração só se pode fazer nos Mezes de Agosto, e Septembro, pois que na prezente estação as aguas q vertem interiormente, não só poem em confuzão todas as terras como até fazem temível a entrada das mesmas Minas, o que deo motivo a que eu não aprezentasse a $V$. Ex $x^{a}$. nesta ocasião o Ouro pimenta, que em huma dellas se acha, e de que vi já uma pequena amostra; assim como a Argilla Micacea, q so nos referidos Mezes, se pode tirar do Rio Saramenho em cujo leito se acha; e para então he que se pode fazer hum verdadeiro exame sobre o Banco de pedras agregadas, que acuza a $\mathrm{m}^{m a}$. carta, sendo agora impraticável a exploração de Rios, que correm quazi todos por entre Mattos. Eu sou com maior respeito possível: $I l l^{m o}$. e Ex ${ }^{m o}$. Senhor Bernardo Joze de Lorena: De V. Ex ${ }^{a}$.: O mais obrigado e fiel súbdito: Domingos Alvares de Oliveira Maciel: Villa Rica 04 de Fevereiro de 1801.

Está conforme. Jozé Joaq ${ }^{m}$. de Oliveira Cardozo Offel. Maior do Ser ${ }^{\mathrm{co}}$. Servindo no impedimento do Secro. do Gov ${ }^{n o}$.

Desde que fora encarregado por Bernardo José de Lorena para percorrer o interior de Minas Gerais e fazer análises químicas de minerais em 1797, Vieira Couto foi responsável por dar informações "circunstanciadas sobre as minas daquele país, como também do partido que dellas se pode tirar". ${ }^{20}$ Em uma de suas primeiras comunicações a Lorena em 1798, indicada como cópia da carta desse governador a D. Rodrigo de Souza Coutinho, ${ }^{21}$ Couto menciona:

Tenho dado principio aos ensaios das Minas, de pois de huma grande fadiga que tive em irigir Laboratório quimico, que nestas alturas foi precizo, que quazi todas as suas numerosas pessas de que he composto, fossem feitas pelas minhas maons, no que consumi infinito tempo. Até o prezente tenho visto huma espantosa quantidade, e vareadade de ferro, e vai tão bem aparecendo seu cobre, que pelo que vejo julgo que a Terra terá tão bem abundancia deste metal: He por ora o que tenho achado $E x^{m o}$. Senhor, porem estou ainda no principio dos meus ensaios, e tenho viajado pouco pelo embaraço que tive na construção do dito Laboratório.

O naturalista aponta na comunicação não só a dificuldade em produzir instrumentos para suas análises laboratoriais dos minerais, que poderiam exigir etapas de calcinação com repetições de sete a nove vezes. Ele destaca ainda a dificuldade de obter cadinhos da casa de fundição do local onde trabalhava e que eram necessários para a análise dos minérios de cobre e ferro que ele julgava serem abundantes. No início de seus trabalhos, Couto foi obrigado a trabalhar na Vila do Príncipe, atual Serro, pois não tinha permissão do Intendente dos Diamantes do Distrito Diamantino (João Inácio do Amaral Silveira, um crítico das atividades científicas realizadas por José Vieira Couto) $)^{22}$ de realizar as buscas por fontes minerais ou de analisar a composição dos mesmos a partir de sua cidade natal.

Ainda proibido de entrar no Distrito Diamantino, Couto descreve em sua primeira memória (cujo manuscrito é datado de 03 de Janeiro $1799,{ }^{23}$ depois impresso pela Revista do Instituto Histórico e Geográfico Brasileiro em $1848^{24}$ e mais recentemente pela Fundação João Pinheiro ${ }^{25}$ descreve o cobre da capitania de Minas Gerais dando a classificação científica da época às diversas formas que encontra, ordenando-as conforme a regra que Lineu havia proposto inicialmente para espécimes botânicos e mais tarde ampliado para animais e minerais. De acordo com Couto, essa classificação se daria da seguinte forma:

\section{Cobre}

Apparece em varias partes desta comarca: rodado no veio dos rios, e ja puro, e mineralizado em vieiros. As especies são Cuprum

Nativum. 2. Lin.

Grisea Wal. sp. 273.2. Dá em quintal de mina 39 libras de Cobre

$$
\text { Ochra }
$$

Aeris. 3. Dá 30 Libras de Cobre em quintal de mina.

Cupri. 4. Dá 30 Libras em quintal ${ }^{26}$

Complementando este manuscrito enviado no início de 1799, uma "Descripção dos Metaes contidos neste Coffre segundo os Systemas de Linneo, e Wallerio"27 (Figura 1) acompanhou a remessa de amostras de minerais e dos produtos de suas calcinações, classificados a termos de seus gêneros e espécies.

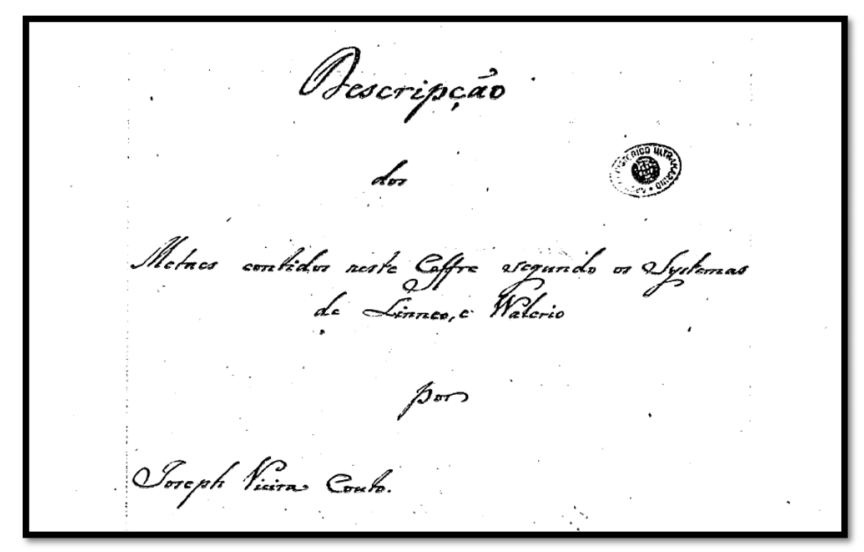

Figura 1. Frontispício do manuscrito enviado com a caixa de amostras

A exemplo do trecho destacado acima, no qual Cuprum ou Ochra são os gêneros e Nativum, Grisea, Aeris e Cupri são as espécies minerais que apresentam características que os definem, a "Descripção dos Metaes contidos neste Coffre" também apresenta a classificação de acordo com o proposto por Waller (Wallerius ou Valério) e sistematizados por Lineu. ${ }^{28}$ No documento, Vieira Couto descreve, além das espécies de cobre, um total de treze espécies diferentes de minérios de ferro, em um total de quarenta e quatro amostras. Envia também uma de chumbo ("das vertentes do Rio Abaitê"), uma de molibdênio (ou "Spuma lupi. 3. Molybdaenum 
tritura rubra"), três de enxofre (na forma de piritas ou $\mathrm{FeS} / \mathrm{FeS}_{2}$ ou de enxofre puro, obtido por meio destas piritas), uma de sulfato ferroso (vitríolo verde ou "Vitriolum ferri vivide hexaedrum") e uma amostra de salitre (ou como descreve, Nitro).

Todas as amostras do cofre têm indicados os locais onde foram coletadas bem como os resultados das análises, apontando na maioria dos casos quanto se poderia obter de metal a partir do minério. O cobre "Nativum - Habita no Serro do Frio na Madre do Córrego, chamado Meia Pataca, três léguas desviado da Contagem da Inhacica. Da 105 libras de cobre em quintal. Couto". ${ }^{29}$ As 105 libras, equivalentes a 48,2 $\mathrm{kg}$, foram obtidas de um quintal, o total de $58,7 \mathrm{~kg}$, o que indicaram um teor de $82 \%$ de cobre na amostra. As demais análises com os outros espécimes de minerais Grisea, Aeris e Cupri renderam na análise, respectivamente, 30,5 e $23 \%$ de cobre. Dois dos minerais de cobre mais comuns, a calcocita $\left(\mathrm{Cu}_{2} \mathrm{~S}\right)$ e a calcopirita $\left(\mathrm{CuFeS}_{2}\right),{ }^{30}$ apresentam respectivamente 80 e $34 \%$ em massa de cobre e poderiam estar associados às descobertas de Couto.

Ainda no mesmo ano de 1799, em 20 de agosto, uma segunda remessa de minerais foi feita por Couto ao governo da capitania e encaminhada a Portugal por Lorena, que faz referência ao

pequeno caixote, que contem quase todo elle Amostras, $e$ Ensaios de inexariveis (sic.) Minas de Cobre. He o condutor de todos os meos officios presentemente o Capitam de Ordenanças Jozé Joaquim Vieira Couto, Irmão do refferido Doutor, o mesmo que eu participei a V. Ex ${ }^{a}$. ter ido examinar a Mina de Galena, de que seo Irmão fez o ensaio. ${ }^{31}$

Nesse novo documento, Vieira Couto requeria ser promovido a algum posto militar, dado a sua idade e doenças que o molestavam. O caixote ou cofre foi levado de Minas a Portugal pelo seu irmão José Joaquim, que além das amostras levou mais "dois sacos de Officios hum de pr $r^{a}$ via e o outro de seg da via" para serem entregues na "Corte na Secretaria de Estado da Repartição d'Ultramar". ${ }^{32}$

$\mathrm{O}$ mesmo ano ainda foi marcado pela chegada da primeira remessa de amostras em Lisboa que foram avaliadas no Jardim Botânico da Ajuda por Alexandre Rodrigues Ferreira, naturalista e líder da "Viagem Philosophica" ocorrida no Brasil entre os anos 1783 a $1792 .{ }^{33}$ Ferreira foi nomeado vice-diretor do Real Gabinete de História Natural e do Jardim Botânico e administrador das Reais Quintas da Bemposta, Caxias e Queluz, e onde desde seu retorno do Brasil dedicou o resto de sua vida à administração metropolitana e a serviços burocráticos, ${ }^{34}$ sem poder avaliar o resultado de sua Viagem. Além de servir de consultor ao governo em alguns assuntos naturais, Ferreira avalia o conteúdo enviado por Couto e comunica suas impressões a João Philippe da Fonseca que:

... tem a Honra de remetter a incluza para o $\mathrm{Ill}^{\mathrm{mo}}$. e Ex $\mathrm{x}^{\text {mo }}$. Senhor D. Rodrigo de Souza Coutinho, a qual achou dentro do Baúl (sic.), onde vem as amostras de Cobre, Ferro, Chumbo, Molibedeno, Ochras, e Vitriolos, q remete seu Collega q foi na Universidade de Coimbra, e também com elle nomeado para as Viagens Philosophicas, das quaes se escusou por molesto Joseph Vieira Couto. Participa igualmente q fica em seu poder a Memória que acompanha os referidos Productos debaixo do Titulo de $=$ Memoria sobre a Capitania de Minas Geraes $=$ juntamente com $a=$ Discripção dos Metaes contidos no referido Baúl = o que tudo fara elle subir promptamente á Presença de S. Ex ${ }^{a}$., sendo essa sua vontade. Jardim Botanico. Em 24 de $7^{\text {bro }}$ de $1799^{35}$

Ferreira não faz nenhuma correção quanto ao conteúdo da memória ou observações sobre os minerais de cobre e ferro enviados na primeira remessa do início de 1799 . Ademais, nota-se no trecho que além de ter sido colega de Alexandre Ferreira na Universidade de Coimbra, Vieira Couto também foi convidado a participar das "Viagens" pelo Brasil.

Causa surpresa que a remessa de Couto tenha atraído as atenções de tantos e tão nobres políticos da Coroa Portuguesa, além de um seleto quadro de naturalistas em um único ano. Tal fato converge ainda para o primeiro contato entre Couto e aquele que seria em Minas Gerais o Intendente Geral das Minas, Manuel Ferreira da Câmara. Em correspondência trocada com Souza Coutinho, Câmara envia seu "Plano sobre a administração das minas de ouro, e meios para que o Estado e o Soberano venham delas a tirar maior partido" junto a uma cópia da memória de Vieira Couto. O futuro Intendente inicia sua correspondência da forma a seguir:

Remeto a V. Exa . a Memoria de Joze Vieira Couto, escrita por ordem de $\mathrm{S} . \mathrm{Mg}^{e}$. Confesso que a li com muito prazer $e$ satisfaçam, vendo $p^{r}$ ella que trabalhou e fez o q' pode com zello ... Rogo todavia a V. Ex . queira ter me $p^{r}$ despeito $p^{r}$ ter sempre dito a $V$. Ex $x^{a}$. que o distrito diamantino, e as Montanhas do Tijuco erão preferiveis a todas que conheço no Brazil pa nelas se fundarem os primeiros estabelecimentos Metallurgicos feitos á Europa; além de que como V. Ex $x^{a}$. me deo a entender mais de huma veiz, e eu estou bem persuadido, não se deve dar muito credito a observaçõens, de quem como eu, deixou o Brazil em idade pouco avançada, para vir aprender o muito pouco, que sabe na Europa. ${ }^{36}$

A memória de Couto se encaixa perfeitamente com os ideais de renovação administrativa das esgotadas minas de ouro e diamantes da Capitania de Minas Gerais, para as quais Câmara propunha ideais de renovação e melhoria. Ele já demonstrava tal interesse desde ter retornado de sua viagem pela Europa com José Bonifácio, o que permitiu à dupla conhecer o sistema de funcionamento de minerações na Noruega, Hungria, Suécia e Alemanha (nesta última os distritos da Prússia, Boêmia e Saxônia). Para Câmara, tais novas propostas deviam ser "introduzidas ellas nos Paízes Diamantinos, onde converia estabelece-la logo de princípio antes de a estender a todas as Minas" ${ }^{37}$ (sublinhado pelo próprio). Ao comparar as propostas de extração mineral de Couto com os pareceres de Câmara, Pandiá Calógeras $^{38}$ afirma que

é de notar-se que no conselho do scientista diamantinense se encontra o germen dos planos posteriormente advogados pelo Intendente Camara, e, em seus detalhes, mesmo nos próprios erros até, ali está o programma da acção seguida pelo governo regencial.

Estimulado por suas primeiras análises e ainda designado para a incumbência de viajar pela Capitania, Vieira Couto conheceu os sertões do Abaeté em 1800 e ao longo de toda sua viagem, desde o Tijuco, passando por Vila Rica e de seu retorno da "Nova Lorena Diamantina", de onde reúne, em uma segunda memória, os relatos sobre achados de minerais como salitre, platina, diamantes, ouro e principalmente o cobre, ao qual dá o maior destaque. A "Memória sobre as minas da Capitania de Minas Geraes", ${ }^{39}$ escrita em 1801, relata em forma de um diário de campo o longo trecho caminhado por Couto, apresentando nela os detalhes de cada dia de viagem, além de presentear o leitor com uma linda e poética descrição da riqueza mineral, vegetal e animal do interior de Minas Gerais. No discurso inicial da Memória, oferecido ao Príncipe Regente, o naturalista escreve que "Hoje ponho na Presença de V. A. cousas, a meu ver, maiores: uma nunca vista sobejidão de cobres (sem nada 
exagerar), além de outros metaes ainda, forma o principal objecto d'este presente trabalho".

Ao longo das primeiras 15 léguas entre Tijuco e Tapanhoacanga (ou entre as localidades de Diamantina e Itapanhoacanga que distam cerca de $110 \mathrm{~km}$ caminhados através da Estrada Real), Couto descreve a descoberta de 4 locais onde encontrou minerais de cobre ocres e cinzentos, que às vezes se apresentavam na "figura de rhombos" ${ }^{40}$ Ele faz um subtítulo no texto com a descrição dos "Cobres do Brazill" e divaga sobre a descoberta das Américas e as "Revoluções geográficas" (fenômenos geológicos) sentidas na Europa, além de comparar as formações geológicas entre tais continentes. Especificamente sobre o cobre, Vieira afirma que

Este metal, que a natureza creou sempre dez vezes menos que o ferro, é no Brazil sem comparação muito mais do que elle; sobeja abastança, que foi ella mesma a causa dos meus erros, dando por ferro, na minha primeira Memoria de 1799, todas as minas que não eram outra cousa mais senão minas de cobre... Sahi a viajar a fim de fazer uma maior collecção d'ellas; phenomeno admiravel! Vi rochas inteiras, montes inteiros, serranias inteiras, que não se formavam senão unicamente d'estas mesmas minas. ${ }^{41}$

Para tais afirmações ele se baseara nos livros de mineração e mineralogia de Johann Gotlob Lehmann e Johan Gotschalk Wallerius, ambos alemães que tiveram obras traduzidas para diversos idiomas nos meados do século XVIII. Couto desmereceu as observações anteriores feitas por outros "habitantes, como por um espirito de adevinho, mas falso, apontavam para estas montanhas, e diziam: Quanto ferro aqui depôz a natureza!'. Ainda no caminho de suas descrições e próximo à Serra do Caraça, Couto explica que a composição dos Marumbés, pequenos seixos ditos satélites dos diamantes, eram na verdade minerais de cobre muito encontrados na Estrada Velha ou Estrada do Mato, entre Tijuco e Vila Rica, principalmente nos distritos de Cocais, Catas Altas, Água Quente e Inficionado.

O caminho entre Vila Rica e os distantes sertões do Rio Abaeté onde a galena argentífera ${ }^{42}$ foi descoberta (Figura 2), também é minuciosamente descrito com uso de seu conhecimento científico em Montanística e de sua linguagem romântica. Em um dos pontos em que atravessa o Rio São Francisco, Vieira Couto aponta a existência de uma pedreira em uma de suas margens em que:

se levantam da borda d'agua dois altos e prolongados lagedos de natureza calcarea, com suas vastas penedias soltas por cima, e cumuladas em ruinas umas sobre outras... Estes, dês da (sic.) borda d'agua até acima ao barranco, mostram em distancias de dois, de tres e mais palmos, sobrepostas umas ás outras, diversas camadas horizontaes muito bem niveladas de um cascalho redondo, tambem calcareo; porêm muito mais negro que a substancia do lagedo, encravado e ferruminado com elle. Este cascalho porém é de uma creação mais antiga que o lagedo, por quanto mostra que se depositára dentro da sua massa em tempos ainda que ella era fluida... Ambos estes lagedos estão salpicados de alto a baixo de pequenas e isoladas ramificações de galena, sem seguirem em veeiros: umas vezes se notam estas mesmas galenas de mistura com pyrites cubicas de cobre e muito miudas, outras vezes estas pyrites se mostram solitarias e sem galena. ${ }^{41}$

Com as informações que nos deixa o naturalista (do rochedo estar logo acima do Ribeirão dos Machados e ao sul da Lagoa da Piracuara) foi possível encontrar o local descrito. Muitas informações dadas por Couto descrevem muito bem o afloramento calcário à beira rio que

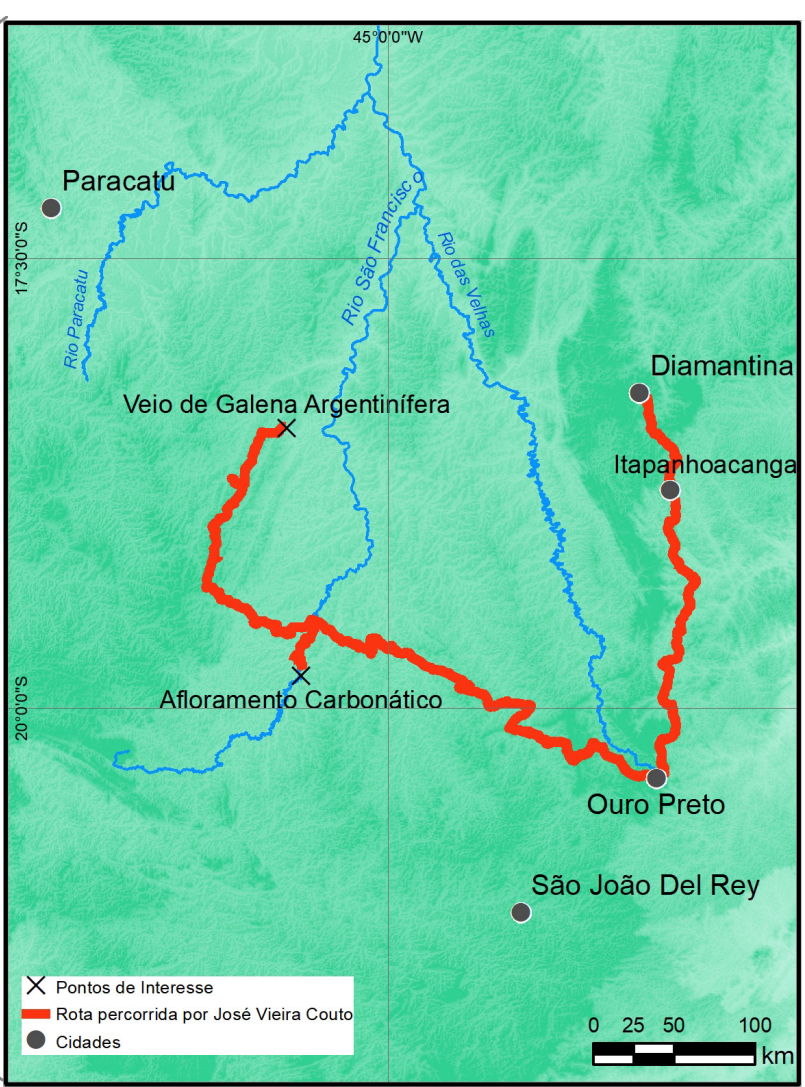

Figura 2. Itinierário da viagem de José Vieira Couto desde Diamantina (Tijuco) até Ouro Preto (Villa Rica) e então para os veios de galena argentífera (um total, ida e volta, de aprox. $1.000 \mathrm{~km}$ ) 

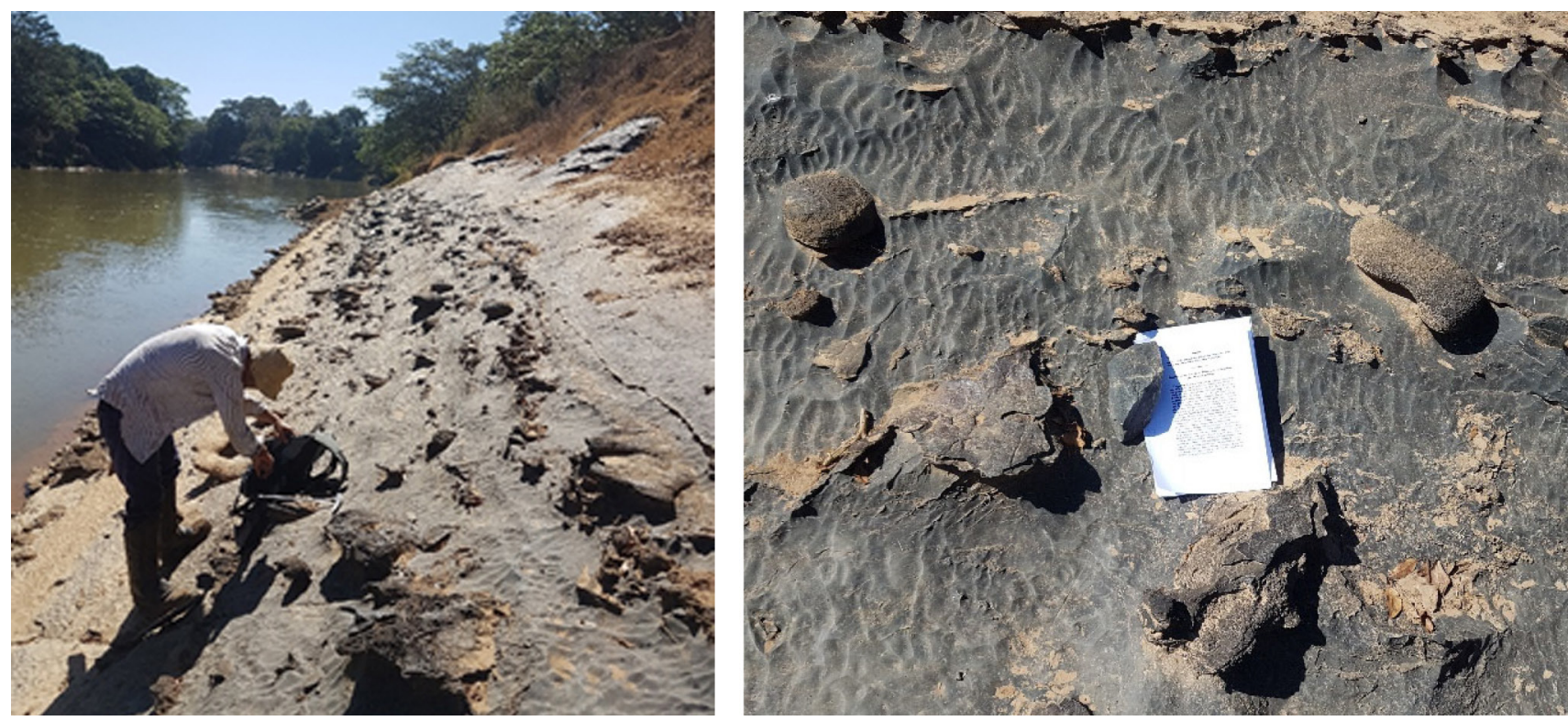

Figura 3. Afloramento carbonáticos à beira do Rio São Francisco apresentando "bolhas" siliciclásticas (a escala na segunda imagem é uma folha de papel A4)

não aparece na margem oeste e que volta a aflorar em outros rochedos no lado leste. O "cascalho redondo" é facilmente identificado em camadas desde a margem do rio (Figura 3 ).

José Vieira Couto justifica seu erro - de tomar por ferro o que agora avaliava como cobre - devido ao fato de ter tido pouco tempo para preparar as amostras e analisá-las em seu conteúdo antes que as enviasse para Portugal. Deve-se considerar ainda as más condições de trabalho na Vila do Príncipe, das quais se queixava que em seu laboratório não tinha os principais fundentes e reagentes que necessitaria em uma análise mineralógica. Eram ainda várias as interrupções demandadas por viagens de que era determinado a realizar. Ainda interessa notar que ele realizava testes por atração magnética com o uso de imãs que fez nos culotes metálicos que obteve de calcinações que levavam de oito a doze horas ou "algumas ainda por demais tempo". ${ }^{43}$

Assim como fez no envio de amostras em 1799, Couto encerra essa memória com a descrição das amostras enviadas. Agora são 59 amostras de cobre divididas em 6 espécies, apenas uma amostra ou espécie de ferro (ao invés das treze descritas anteriormente), duas de chumbo e uma de bismuto nativo. Apesar de aumentar em quantidade de amostras, as análises dos teores de cobre das mesmas seriam agora mais modestas que daquelas apresentadas na primeira remessa, com uma média de 15 libras por quintal (que equivale a $47 \%$ de riqueza do metal),${ }^{44}$ e na amostra mais rica apresentando um teor de 40 libras por quintal. Contudo, o ensaísta apresenta uma justificativa para esse desvio ao afirmar que

quasi sempre poder-se-hão calcular os productos d'estes meus ensaios para cima ainda d'aquelles, que presentemente vão calculados. Se Deos porem me der vida e tempo, eu os publicarei um dia, de maneira que elles vão a meu gosto, $e$ apareçam dignos do benefico Soberano, por ordem de quem trabalho.

Outra interessante nota indica que ele não tem em sua posse para análise de "finos" (ou seja, da presença de ouro e prata) em conjunto com o ácido nítrico, a "água-forte", ou ácido clorídrico que era necessária para dissolver os culotes obtidos na calcinação. Apesar disso, esta segunda memória de Vieira Couto parece não ter atraído a mesma atenção dos demais naturalistas, políticos brasileiros ou portugueses, pois não constam ou não foram encontradas tantas referências à descrição dos minérios de Minas Gerais que davam maior atenção ao cobre.

Também é curioso apontar que em sua terceira memória, na qual aborda as nitrateiras de Monte Rorigo, Couto volta a descrever os afloramentos minerais ao longo do trajeto que realizou de Tijuco até o local onde o salitre era extraído na barra dos rios Cipó e Paraúnas. Como já havia sido apontado por Silva, ${ }^{45}$ entre o que foi escrito por Couto no manuscrito original de $1803^{46}$ e a versão que foi publicada em $1809,{ }^{47}$ são notadas diversas diferenças no texto e a maior parte delas no que faz referência à substituição dos minérios, primeiro indicados como sendo de cobre no manuscrito e que foram trocados no livro por minérios de ferro, o que pode ser apontado como uma correção tardia de suas observações e análises. Isto pode ser comprovado ao longo de vários trechos, como os destacados no quadro a seguir (Tabela 1).

Todas estas observações são feitas à medida que realiza seu "Itinerário Mineralogico observado na occasião da diligencia de Monte Rorigo". No livro, o naturalista tijucano não se refere em nenhuma passagem à existência de minérios de cobre, substituindoos em grande parte pela indicação de minérios de ferro, dentre eles a hematita e o oligisto. Ele ainda apresenta para a versão do livro a existência de outros minerais de manganês (ou como denomina, Manganesio) além de trazer a classificação de Werner para alguns dos minerais encontrados, fato que não ocorre no manuscrito. Além destes ele indica a existência de xistos (Schistos), seixos rolados de quartzo e a "Actinote fibrosa", provavelmente um xisto verde.

Os fatos que podem ter motivado a correção do manuscrito podem se dever ao novo ambiente político na Europa devido ao avanço das tropas francesas na Península Ibérica. Além de ter culminado na vinda da Corte Portuguesa para o Brasil, as atenções na colônia se concentravam agora na necessidade de armar seus exércitos com pólvora, o principal derivado do salitre que Couto descreve com mais enfoque nesta nova memória. Além disso, seu 'padrinho' D. Rodrigo de Souza Coutinho, era empossado como Ministro da Guerra no Brasil e despachava agora do Rio de Janeiro onde veio a falecer em 1812.

Uma quarta memória outra vez coloca em dúvida a verdadeira identidade das amostras coletadas e ensaiadas por Couto. Manuscrita no intervalo entre o manuscrito sobre as nitreiras de Monte Rorigo de 1803 e o livro publicado em 1809, uma cópia dessa "Memoria sobre as Minas de Cobalto da Capitania de Minas Geraes" pode ser encontrada como o anexo de uma comunicação entre José Bonifácio 
Tabela 1. Comparação entre os textos de Vieira Couto, redigidos em anos diferentes

Manuscrito de 1803

A primeira legua he quase toda de terra areienta e saibro branco: aqui e ali se vem algumas minas dispersa de cobre (fl. 49)

A descida era longa, o caminho fragoso, e cujas fragas ou erão de hum quartzo branco, cor de leite, ou penedias cinzentas, grandes, bastas, e todas minas de Cobres. Mais para a fralda da serra vião se outras minas, como o Azul de cor ferrete, ou semelhante do anil em pedra (fl. 54).

Emboquei por este valle, que não deixava de ser ameno, e suas duas serras admiraveis, pela altura, e grandeza das fragas. De longe em longe se vião dispersas minas de Cobre (fl. 66).

Pouco vai daqui á Bandeirinha, e na paragem onde se principia a avistar, atravessão a estrada grossos vieiros da mina vermelha de Cobre (fl. 67).

... na sua passagem que guia para o Corralinho, a mesma mina (de cobre) em montes. Esta se dirige ate a chacra, chamada da Viuva, e se espalha ao largo por aquelles arredores, debaixo da figura ja de outras espécies, e em grandes quantidades. Passado o rio, e as altas fragas, que ficão de fronte, no alto, em terras campinas, pyrites cubicos de Cobre, e de cor escura. Começando-se a subir o morro, que ao depois descamba para o Corralinho, todo elle se compõem de mias amarelas, retinadas, e muitos curiosos petrificados de madeiras, tudo Cobre. Dexando-se o sítio do Máo Cabello á esquerda, segue-se por chapadas e campos: a terra he lastrada de hum saibro branco, que corre das montanhas que ficão á esquerda, e esse saibro he todo elle salpicado de pedrinhas negras, também minas de Cobres. Muitos quartzos se vem por até tintas de verde, sinal de quanto abundão em Cobres estas mesmas minas. Ao descer para a Olaria, pouco antes de chegar a ella, em grandes rasgões, feitos pelos enchurros, notão-se, em vieiros de quartzos, minas negras de Cobres, em fibras delgadissimas, paralelas, e algum tanto retinadas. Depois que se larga o Quartel da Itaipaba, ao descer para a ponte do Gectinhonha, gorgulhos da mina vermelha. Passada a ponte, grandes montes da mina azul, que negrejão pelas estradas, e as lastrão por largo espaço. Os morros de puros quartzos, que ficão á esquerda, cobrem-se das mesmas pyrites cubicas. Ao atravessar o espigão, que dista para o Gectinhonha do Campo, na raiz do dito espigão a mesma mina azul em grossos vieiros de quartzos. Depois do logar chamado o Areião, da-se principio a hua longa subida, quase de legua; por toda essa subida ve-se á cada passo repassar a estrada muitas minas de Cobre, e pela maior parte da vermelha. (fl. 68-71).

de Andrada e Silva e o Visconde de Anadia (João Rodrigues de Sá e Melo, então Secretário de Estado da Marinha e Ultramar) de 1806 em Coimbra. ${ }^{48}$ Essa memória, escrita em 1805, vem corrigir mais uma vez as análises feitas pelo naturalista do Tijuco, que dessa vez tomava por minerais de cobalto a maior parte das amostras coletadas por ele, ao contrário do que inicialmente indicou ser ferro e depois cobre. Em suas palavras, Couto afirma que "Em outro tempo eu dizia - O Cobre he o metal dominante do Brazil, hoje é o Cobalto" (grifo de Couto). ${ }^{49}$ Sua justificativa para mais essa falha se daria devido ao método que usou nas calcinações pois uma vez que a adição de chumbo como fundente não era suficiente para auxiliar na separação dos metais ele usava o acréscimo de cobre metálico para esse mesmo fim. Descrevendo suas amostras anteriores, afirma Couto que:

Seguiu-se a minha segunda remessa de metaes: pertendia então que jáfossem purificados estes Culotes, $p^{a}$. o q'escolhi o metodo de os escorear pelo meio do Chumbo no forno de Cupella. Descuidado q' me havia com o Cobalto, metal de dificil fusão, e q'além disso por sua natureza repugna vitrificar-se com o Chumbo; depois de horas perdidas $e$ cançadas, vi q' estes Culotes resistião fundir-se, nadavão sobre o banho do mesmo Chumbo, inchavão, fazião-se porosos, e a final nunca conceguia suas purificações. Estes fenomenos os imputando a abundancia do ferro contido nesses Culotes, lembrou-me então acrescentar-lhes Cobre
Livro de 1809

A primeira legoa he quasi toda areienta, saibrosa, aqui e ali se notão algumas minas dispersas de ferro da espécie oxidado rubiginoso (p. 53)

A descida era longa, o caminho fragoso, e estas fragas ou erão de quartzo branco, ou de grandes e bastas chapas de Schisto. Mais para a fralda da Serra, cruzavão a estrada em varias partes cintas de Manganesio da espécie negra (p. 54-55).

Emboquei por este vale, que não deixava de ser ameno, e suas serras admiraveis pela altura e grandeza de suas fragas. De longe em longe notavão-se algumas minas dispersas de ferro (p. 58).

Pouco hia daqui ao Quartel da Bandeirinha, e na paragem donde se principia a avistallo, atravessão a estrada grossos vieiros da espécie oxydado rubro de ferro (p. 59).

...na sua passagem, caminho do Curralinho, a mesma mina (de ferro) em montes. Esta se dirige em varios ramos, que se espalhão ao largo por estes arredores, e debaixo tãobem da forma de outras espécies, como do Oligisto. Passado o rio e humas altas e isoladas penedias, seguem-se terras campinas, lastradas da mina de ferro sulfurado decomposto (ferro hepático de Lisle). Começando-se a subir o morro, que ao depois descamba para o Curralinho, todo elle he composto do ferro oxydado hematite irisado (Hematites parda. Werner.), oxydado rubiginoso, e de muitas curiosas concreções (petrificados) desta ultima variedade. Deixando-se o sitio do Máo Cabello á esquerda, segue-se por chapadas e campos: o caminho he aqui lastrado de muitos quartzo-hyalino opaco e leitoso, que correrão dos montes visinhos, que ficão á esquerda, e entre estes quartzos observão-se muitas pedras negras, redondeadas (piçarra Silicea Werner.) como tãobem, quantidade de quartzo verdeado, redondeados tãobem, e que se despregarão das rochas visinhas, onde ainda existem muitos delles encravados, e formando huma espécie de poudding com ellas. Ao descer para a Olaria, e pouco antes de chegar a ella, observa-se em grandes rasgões formados pelas enxurradas, a Actinote fibrosa (pedra radiada commum. Werner.) envieirada em quartzo, negra, em fibras delgadas, parallelas, e algum tanto setinadas. Passada a ponte da Gectinhonha, e seguindo rio abaixo, grandes montes de Manganesio negrejão pela estrada, e acompanhão por grande espaço, de mistura com o ferro Sulfurado decomposto até chegar a outra ponte da Gectinhonha do Campo, distancia de quasi legua. Depois de passar-se o lugar chamado o Areião, tudo he huma subida fragosa quasi de légua, e por toda ella vem-se a cada passo repassar a estrada veias e lastros de minas de ferro, pela maior parte da espécie oxydado rubro (p. 59-60). já refinado, $p^{a}$. desta maneira lhes aumentar a fusibilidade e facilitar suas incorporações com o Chumbo.

Os testes indicavam que o metal cobalto era obtido em forma de liga com o cobre após o adicional acréscimo deste último como fundente, fazendo com que acreditasse que o culote final obtido teria em massa o conteúdo adicionado do fundente e do metal contido no minério que nas primeiras análises "mostravão acréscimos, cujos os calculava como pertencendo ao Cobre contido na mina, e hoje vejo q' não era senão do Cobalto". No entanto, os indícios e análises que apontavam a descoberta de cobalto por Couto serão tratados mais adiante neste artigo. Aqui é ainda interessante destacar uma observação feita por Richard Burton ${ }^{50}$ em sua obra na qual descreve sua viagem pelo Brasil. Em uma nota de rodapé Burton indica que o "Dr. Couto declares these Marumbés or Marumbis, which he writes 'Marombés' to be copper ore of the ash-coloured (cinzenta) species. But he certainly had copper on the brain". Outro naturalista e mineralogista inglês, John Mawe, durante sua estadia em algumas localidades da Capitania de Minas Gerais, aponta outra curiosa passagem ocorrida enquanto acompanhava os ensaios de ouro na Casa de Fundição de Vila Rica:

Quantidades consideráveis de pirites arsênicas, ditas serem de cobalto, foram trazidas até a mim: eu examinei alguns espécimes com o maçarico, mas não encontrei nenhum 
vestígio desse metal, já que a substância em nenhum estágio transmitiu a cor azul ao bórax ou ao vidro. Piritas marciais são encontradas na cidade, onde há um veio muito forte delas no quartzo. Antimônio foi trazido para mim de alguma distância, e também alguns pedaços de cobre muito oxidados, que se dizia serem encontrados nas lavagens de uma cidade chamada Caldrones, mas a este respeito eu tinha muitos motivos para duvidar. Não poucas imposições a respeito da descoberta do cobre foram submetidas a mim. Um homem trouxe um pedaço arredondado de jaspe, com cerca de uma onça de peso, e com ela metade de uma onça em cobre, da forma e do tamanho de uma bala de caçada de pato, que ele me disse ter sido produzido fundindo uma pedra semelhante ao jaspe na minha frente. Com muita dificuldade, convenci-o de que a pessoa que realizara a operação deixara cair uma moeda de cobre no cadinho. Fiquei surpreso ao descobrir que muitas pessoas, mesmo senhores de alguma posição social, tinham a noção de que quase todas as pedras de cor vermelha na calçada das ruas eram de cobre. Um indivíduo divulgou um relatório dizendo que ele possuía várias peças ricas naquele metal; mas, ao ser convocado e interrogado de perto, ele declarou que os havia perdido na mudança para outra casa. Não é de surpreender que histórias desse tipo recebam crédito fácil entre pessoas estimuladas pela avareza e cegas pela ignorância, e que os homens engenhosos que as inventam e propagam devem ser tentados pelo sucesso a repetir suas imposições e corromper os outros pelo seu exemplo. Os ricos minérios de ferro com os quais o distrito é abundante, e dos quais eu vi muitos espécimes, poderiam fornecer emprego muito mais lucrativo do que lavar ouro, ou seguir outras especulações ociosas e quiméricas

O que apontam Burton e Mawe está associado às descobertas de Couto sobre cobalto e cobre cujas análises pelo segundo inglês não apontavam a presença dos mesmos. No entanto no seu livro, Mawe menciona a existência de cobre nativo nas proximidades do Tijuco, que lhe foi apontado pelo Intendente Câmara, para o qual "pequenas partículas aparecem em uma rocha de quartzo e hornblenda: a matriz é tão dura, e a quantidade de cobre é tão trivial, a ponto de não encorajar o trabalho nisso". ${ }^{51}$

Em 1811 começa a atuar nas inspeções das minas da Capitania o alemão Barão de Eschwege que, vindo de Portugal após trabalhar com José Bonifácio, continuou com as viagens por Minas Gerais iniciadas por Couto em busca de novas fontes minerais. No mesmo ano de sua chegada a Vila Rica, Eschwege se comunica com o Conde da Barca, Antônio de Araújo de Azevedo, relatando que:

Derão-me algumas amostras de Chromate de Chumbo e dizem que o ha em abundancia n' hua lavra perto de Mariana. Mandarão a pouco tempo hua quantidade de Cobre nativo pa a fundição, q' sahio segundo a descripção de hum grde vieiro alguns legoas d'aqui. Eis aqui tantas cousas uteis em q' me posso ocupar, e no meio do caminho me querião fazer retroceder. ${ }^{52}$

Além de indicar a presença de dois importantes minerais, Eschwege está se queixando das ordens que havia recebido de retornar ao Rio, onde seria Chefe do Gabinete de minerais além de ser indicado a dar aulas de mineralogia a nobres brasileiros. Os indícios sobre a mina de cobre apontam para os locais por onde Vieira Couto passara em sua segunda viagem mineralógica, no qual descreve a existência de algumas jazidas em Inficionado.
Ainda em 1811, o Conde da Barca comunica esse e demais achados minerais feitos na capitania ao ex-Vice Rei do Brasil e agora Secretário de Estado dos Negócios do Reino, Fernando José de Portugal e Castro (o Conde de Aguiar), sobre as "vantagens, que se poderião tirar do exame das Minas de Cobre do Inficionado, da de Enxofre e Ferro do Sítio de Antônio Pereira, e de outros minerais que ainda possam se encontrar nas vizinhanças de Villa Rica" que ficaram a cargo do "Sargento Mor do Real Corpo de Engenheiros Guilherme de Eschwege" que poderia operar nessas minas e na Real Mina de Galena, desde que não houvesse a necessidade do pagamento dos quintos ou de quaisquer outros "novos impostos". ${ }^{33}$ Eschwege reafirma essa informação por uma carta ao Conde da Palma, Dom Francisco de Assis Mascarenhas, o então governador da Capitania, cujo teor completo é descrito abaixo:

\section{Illmo. e Exmo. Senhor}

Sendo o objecto da Mineração não somente d'oiro mas também de outros Metaes hum dos principaes pa. afelicidade dos povos desta Capitania, e tendo eu achado boas indícios pa. a abertura de hua Minas de Cobre perto do Arrayal de Inficcionado, acho mto. Conveniente pa. o interesse de S. A. R. e dos povos, por maõ a esta mina, ou por conta da Fazenda Real, ou por conta d'algua Sociedade particular. Mas tenho de advertir, q' por conta da fazenda Real naõ correspondera tanto o interesse ao trabalho por cauza dos mais empregados $q^{\prime}$ entaõ saõ percizos, e principalmte. $p^{l o}$. lucro $m^{t o}$. moderado $q$ 'ordinariamte. costumão dar estas minas. Por conta d'algua Sociedade [nota bene debaixo da Administraçaõ Regia ou melhor de dizer debaixo da Inspecção de hum homem habil, authorizado por S. A. R. de dirigir os trabalhos desta mineraçaõ conforme as regras da arte] seria a todos os modos mais vantajoso concedendo $S$. A. R. a licença $p^{a}$. isso e havendo $S$. A. $R$. a graça de naõ exigir nos primeiros annos da Mineraçaõ desta mina direitos alguns, e depois somente o dizimo e não o Quinto.

Estou certo representando Va. Exa. este objecto a $S$. A. $R$. e alcançando esta graça $q$ se achará com facilidade

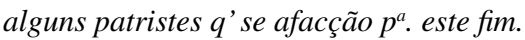

Va. Rca. $5^{\circ}$ de Janro. 1812 de Va. Exa.

Illmo. e Exmo. Senhor Conde de Palma $m^{\text {to }}$. at ${ }^{\text {to }}$. Ven ${ }^{\text {do }}$. e $v^{\text {rdo }}$. Guilherme, Barão de Eschwege. ${ }^{54}$

Eschwege dá mais esclarecimentos sobre esta provável mina de cobre em Inficionado (atualmente chamado de Santa Rita Durão e distrito de Mariana, próximo a Catas Altas) no seu livro Pluto Brasiliensis em que informa sobre a "areia fina, nos córregos que nascem ao pé da Serra do Caraça" "55 que apresentava cobre nativo. Ele atribui a descoberta ao já finado Capitão Durães (na verdade Domingos Durão Coutinho, falecido antes de 1808) ${ }^{56}$ enquanto buscava ouro aos pés da serra. No entanto, apesar dos esforços de Eschwege em buscar junto ao governo fundos para que pudesse extrair metais dos minérios, ao engenheiro coube apenas instruir o dito capitão da forma como poderia empreender na mina "sobre o modo e o local onde deviam ser realizados os serviços." No entanto, seus esforços não são produtivos, uma vez que na sua ausência o capitão dispenderia muito além de suas possibilidades financeiras ao seguir conselhos dados por um cirurgiãomor, Caetano José Cardoso, de Vila Rica. Em uma das notas de seu livro, Eschwege chega a citar que analisou uma pequena barra de cobre obtida pela areia cuprífera do Inficionado. ${ }^{57}$ É interessante ainda notar que o nome do arraial do Inficionado talvez se deva à presença de cobre em ligas metálicas naturais do ouro que era ali extraído, conforme nos aponta o Imperador Dom Pedro II que descreve em seu diário de visita a Minas em 13 de Abril de 1881: 
Arraial do Inficionado depois de margear o ribeirão do mesmo nome. Assim chamado por causa de bexigas que aí houve, ou de cobre de sua mineração que venderam com o ouro por este metal dizendo-o por isso inficionado. ${ }^{58}$

As bexigas se referem às doenças que acometeram os exploradores de ouro no século XVII que, por causa disso, podem ter denotado o nome do arraial ou ainda o sentido de inficionado, ou infeccionado, era dada àquele ouro de baixo quilate que não atenderia bem ao seu comércio por tratar-se de um ouro menos denso e de coloração acobreada. Essa indicação de ouro empobrecido também é destacada pelo poeta José de Santa Rita Durão no Canto IV de seu livro Caramuru, escrito em 1718, cujos versos da vigésima primeira estrofe denotam que

\section{Nem tu faltaste alli, Grão Pecicava, Guiando o Carijo das aureas terras; Tu que as folhetas do ouro, que te ornava, Nas margens do teu rio desenterras:

\author{
Torrão, que do seu ouro se nomeava, \\ Por crear do mais fino ao pé das serras; \\ Mas que feito em fim baixo, e mal prezado, \\ $O$ nome teve de ouro inficionado. ${ }^{59}$
}

Voltando mais uma vez à obra de Eschwege, Pluto Brasiliensis, ${ }^{60}$ percebemos que o alemão parecia conhecer a mesma fonte de cobre nativo descrita tanto por Couto quanto por Mawe nas proximidades do Tijuco, apontando que o mesmo achado ocorre no distrito de São Domingos do Serro do Frio. Eschwege aponta também a Fazenda dos Caldeirões (e não 'cidade de Caldrones' como se referiu Mawe), localizada próxima a Ouro Branco entre Vila Rica e Congonhas do Campo, como local onde se encontravam minerais de cobre como a cuprita (um óxido de cobre) e a malaquita (um carbonato).

Outra referência sobre o achado de cobre em Minas Gerais foi escrita em torno de 1822 no período em que José Bonifácio era o Secretário de Estado dos Negócios do Reino "por hum seu collega" José de Sá Bitencourt Câmara, irmão do Intendente Câmara e também naturalista. Ao avaliar em sua obra a "Memória mineralogica do terreno mineiro da Comarca de Sabará" - publicada na Revista do Archivo Público Mineiro (APM) em $1897^{61}$ - identifica-se uma interessante análise química feita em "hua amostra de cobre nativo q. ${ }^{e}$ se achou nas vizinhanças do Arraial do Brumado q..$^{e}$ lhe dera Sujeito no Arraial de S. João". Em sua análise, José de Sá faz dissolver a amostra de cobre que lhe foi dada por um francês de nome Cláudio:

... em acido nitrico e p.r q.e era fraco lancei-lhe um pouco de acido muriatico que o desolveo fazendo a dessolução verde lancei-lhe alkali volatil e tomou logo a dessolução a cor de azul de prussia q.e fez precipitar o verdete sem deichar corpo algum diferente. O Francez me segurou conforme q.e se podem carregar cem bestas: a porsão q.e analisei foi pequena e era como folhetas roladas, e bastante maleável. Não cito o lugar por q.e o descobridor o não tem manifestado ${ }^{62}$

Na análise descrita, José de Sá deve ter obtido o complexo de nitrato ou cloreto de tetra-aminocobre (II), que apresenta coloração azul escura e intensa, característica da coloração do azul da Prússia, o hexacianoferrato(II) de ferro(III).

\section{O COBALTO}

Ao contrário do cobre que já era conhecido há milênios, o cobalto, que é raramente encontrado em sua forma nativa na natureza, foi o primeiro metal descoberto no século XVIII a partir do uso de técnicas científicas. ${ }^{63}$ Contudo, a utilização de derivados do cobalto como corante de intenso azul para vidros e cerâmicas era do conhecimento chineses, egípcios e persas a cerca de 1500 a.C. O isolamento do cobalto e sua descoberta como novo elemento químico foi feito por Georg Brandt, um químico e mineralogista sueco em 1735. Ele isolou esse metal do "Zaffer", um aditivo utilizado na Europa para a produção de vidros com coloração azul, e no mesmo trabalho ${ }^{64}$ Brandt diferenciou o cobalto do bismuto, metais sempre encontrados juntos em minerais na Europa. O nome desse novo elemento deriva de antigos trabalhos de mineiros e ferreiros que ao ensaiar em fornos minerais que continham o cobalto eram afligidos por "doenças divinas". Por isso, o nome "cobalto" pode ter derivado do termo alemão "Kobold":

\begin{abstract}
que significa "demônio", ou, de acordo com uma antiga lenda germânica, espíritos malignos das minas, parecidos com os gnomos. A etimologia que evoca goblins ou gnomos também levanta outra possibilidade. A origem da palavra talvez seja explicada pela altura corporal dos mineradores. Provavelmente a exploração das minas na Saxônia exigisse trabalhadores de pequeno porte, como ocorreu anteriormente nas antigas minas de Laurium, na Grécia. ${ }^{65}$
\end{abstract}

Atualmente o cobalto tem enorme aplicação na produção de ligas magnéticas como as utilizadas em equipamentos de ressonância magnética, baterias de íon-lítio e semicondutores, mas ainda é principalmente utilizado para produção de corantes e tintas azuis. ${ }^{66}$ O maior produtor mundial de cobalto é a República Democrática do Congo, que produz cerca de $50 \%$ do metal consumido no mundo, enquanto o Brasil teve em 2013 uma produção de apenas 3\% do montante, sendo todo esse total (ca. de 3.500 toneladas) produzido como subproduto do refino de níquel. ${ }^{67}$

O primeiro relato histórico encontrado sobre o achado de cobalto no Brasil é feito por Domingos Alvares de Oliveira Maciel, irmão de José Alvares Maciel, que havia sido incumbido de averiguar o informe sobre achados minerais feitos pelo químico inconfidente. Conforme indicado em carta a Bernardo José de Lorena em 1801 no envio de amostras de minerais e produtos de algumas minas indica a existência de um veio rico em arsênio e "de três pes de largura em partes se faz ainda mais apreciavel pella quantidade de Cobalto, que contem." ${ }^{68}$ É muito provável que José Vieira Couto conhecesse este relato de José Alvares Maciel uma vez que também é citado na correspondência. No seu manuscrito de 1805 com a "Memoria sobre as Minas de Cobalto da Capitania de Minas Geraes", ${ }^{69}$ o tijucano recorrige suas observações que primeiro apontavam abundância em minérios de ferro e depois de cobre. Em suas palavras, Couto nos informa que:

Tal hoje me acontece: estas multidões de minas que algum dia me espantarão, e parecerão-me primeiramte. Ferro, Cobre ao depois, hoje retrilhando o Caminho Velho, fitando melhor os objectos, descubro q' esta maior parte, q' este maior numero dellas, he tudo Cobalto. Este metal raro q' a Natureza escaçamte. o repartiu, e por cuja causa os Naturalistas acerca dele são tão concisos; Este metal forma quasi toda a superfície de nossa Capitania ${ }^{70}$

Um fato que pode explicar sua nova afirmação - de estar lidando com o cobalto e não com cobre - é que, assim como o ferro, o cobalto apresenta características magnéticas ${ }^{71}$ e também pode ser atraído por imãs e assim identificado em ensaios laboratoriais. 
Com seu tom poético, na continuação do texto acima, Couto aponta como minérios de cobalto o material negro das montanhas, de brilho de aço polido, de "encarnado vivo ou cor de rosa", amarelos, verdes e até mesmo brancos: "tudo he Cobalto". Ele relaciona a descoberta desse metal sempre acompanhado do chumbo, sem que se encontre o bismuto " $q$ ' he o metal $q$ ' mais acompanha o Cobalto em Europa". ${ }^{72}$ Para as análises que descreve, Couto aponta uma série de dificuldades e necessidades de conhecer os minérios corretos, fundentes e da falta de entendimento de demais ensaístas que talvez não pudessem ter obtido anteriormente os culotes do metal em suas oficinas.

Essa memória manuscrita, conforme fora indicado anteriormente neste artigo, consta como parte anexa da carta que José Bonifácio de Andrada e Silva enviou ao Visconde de Anadia em 1806, dando informações sobre os trabalhos de Vieira Couto. Na carta, Bonifácio faz observações que corrigem as informações dadas por Couto referentes às análises feitas pelo tijucano e indica que de "todos os mineraes q' me forão enviados, nenhum deles he Cobalto" ${ }^{73}$ Das trinta e cinco amostras enviadas em um caixote (em repartições divididas por “ $§ I$ - Cobalto em Liga com ferro nativo", " $§ I I-C o b a l t o$ mineralizado com arsênico e enxofre", " § III - Cobalto em estado de óxidos sulfurados" e " $\$ \boldsymbol{I V}$ - Cobalto em estado de arseniatos. Cobaltos em eflorescências. Cobaltos terrosos"), Bonifácio as classifica como sendo dezenove amostras de minério de ferro e de derivados ferrosos, duas de manganês, duas de rutilo, duas de jaspe, uma de berílio, uma de cianita, uma de xisto, uma de turmalina e uma de cada espécie que denomina como Actinote, Trapp, Lapis Ladius e Lithomarga, mais uma espécie que afirma não conhecer, não reconhecendo nenhuma delas como minério de cobalto. As observações de Bonifácio foram anotadas às margens da cópia do manuscrito de Couto logo nos cantos esquerdo ou direito da descrição das amostras (Figura 4).

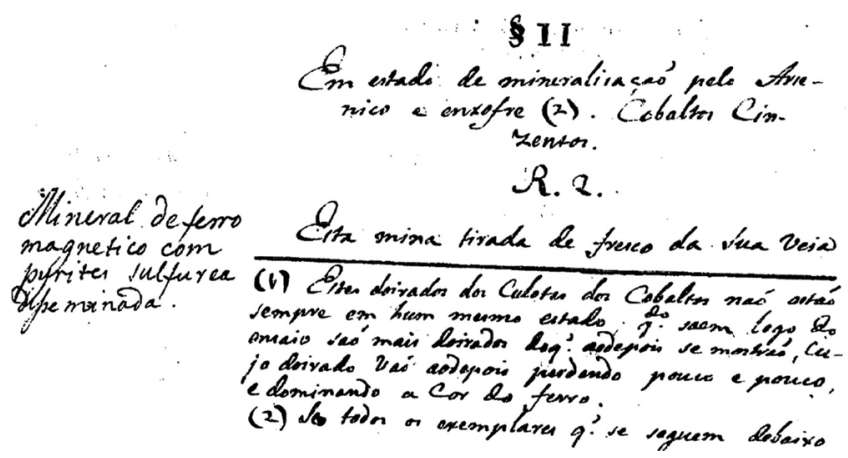

Figura 4. Trecho do manuscrito da "Memória sobre as minas de Cobalto..." enviado por Vieira Couto a Portugal descrevendo amostra do mineral enviado (à direita) e observações feitas posteriormente por José Bonifácio (à esquerda) após realizar seus ensaios (AHU, CX. 182, D. 53, C. 13451)

Apesar dessa séria constatação, José Bonifácio atenuou as falhas de Vieira Couto dizendo que ele "não he Mineralogista e nem Docimasta mas he um Moço trabalhador; e que tem zello pella commissão de que foi encarregado; pois já com esta são quatro as remessas que tem mandado". ${ }^{74}$

No entanto, o companheiro de viagens de Bonifácio pela Europa em sua excursão científica não exprimiu a mesma observação. Manuel da Câmara Bitencourt teria tido como incumbência, ao chegar em Minas Gerais, de procurar os sítios descritos por Couto onde o cobalto foi encontrado por esse último. No entanto, ao se comunicar com seu amigo, o Conde da Barca, faz uma queixa sobre os trabalhos de Couto: ${ }^{75}$ aqui logo vi nam caber nas minhas forças por nam haver no Pais o que V. Ex $x^{a}$. me pedia, o Cobalto de Tijuco. Se tivesse mais vagar contara $a \mathrm{~V}$. Ex $x^{a}$ a historia completa desse pertendido Cobalto, dado a Tijuco pelo Doutor Joze Vieira Couto, o qual antes de saber distinguir os mineraes de Cobre dos de Ferro, deu a estes o nome daqueles, e convencido por fim que não erão da Natureza que diria, chamou as mesmas Cobalto, que elle ainda conhecia menos. Estando em $L^{\text {oa }}$. tive ocazião de estudar de perto seus erros $p^{r} q$ o Ministério me fez sempre juiz das suas remessas; e o peor não foi errar, mas foi ajuntar a conhecidos mineraes de ferro butoens de cobre que elle dizia ter obtido pelo Ensayo; e porque nam apoiei semelhantes imposturas, que so faz $q^{m}$ não tem que perder, e fazem se a quem lhe não sabe dar o devido valor, nunca me vio com bons olhos. - Chegando depois a Tijuco achei methamorfoziados aquelles mesmo mineraes em mineraes de Cobalto. V. Ex . poderá a vista disto prezumir que pezo poderia eu dar a essas suppostas descubertas, conhecendo tam bem, que não erão a mor da verdade mas vontade de impor que lhes dava nascimento: nam lhe falei nunca em tal, e menos a contradisse athe que hum dia hindo a sua caza ver os productos do Abaite, mostrou me hum pouco de Escoria de ferro e propriamente de (?) que as vezes toma a cor azulada e me deu que era aquelle o vidro do Cobalto que elle havia descuberto: foi precizo muito gesto, e muita manha para lhe mostrar q aquella sorte de vidro, não era corado senam pelo ferro, e ficou ao que julguei convencido porque lhe mostrei, que o vidro de Cobalto era sempre transparente e aquelle sobre translucido era opalizante e tomava contra a luz a cor parda. Dize me então que tinha descuberto outra mina de Cobalto sem todavia, como sempre costumou nas suas Memorias marcar o lugar; mina em que eu acredito minas que não procedentes, salvo se o Cobalto exista aqui por differente nada de que nos outros paizes onde se extrahe; aqui sendo provido nam he provável nam aparecem aqui traços de Nikel e d'arsenico ou Mispikel, companheiros inseparáveis do Cobalto; e sendo tudo isto assim he me impossivel satisfazer a V. Exa. enviando lhe o Cobalto de Tijuco mandei buscar hua coiza que me dizem que lhe chamara Cobalto, se vier a tempo lha remetterei (... ilegível ...). Quanto aos outros mineraes há por aqui muito poucos a exceção d'alguns Titanos, e demais minas de Ferro, que nunca poderam ser aproveitadas por falta de lenhas.

É também em comunicação ao Conde da Barca que Eschwege e, novamente, Manuel da Câmara, se refeririam à busca pelo cobalto indicado por Vieira Couto. O alemão escreveu primeiro no dia 20 de Novembro de 1811 (ao narrar sua viagem em busca de um vulcão noticiado por posseiros nas regiões do Rio Doce, a leste da Capitania), no caminho de retorno a Vila Rica, uma breve passagem pela Vila do Príncipe e Tijuco, onde reconhece os grandes feitos de extração de diamantes e metalúrgicos do Intendente Câmara "arrodiado de tantos ignorantes". Eschwege afirma ainda que por:

dois dias andei em procura do Cobalto athe finalm ${ }^{\text {te }}$ o achei, mas em tam pequena quantidade q não vale a pena, era so superficialm ${ }^{\text {te }}$ a hum schisto argiloso sem ser em vieiro. o Camera acredita finalm ${ }^{\text {te }}$ o facto $e$ he bom $q^{\prime} V$. Ex $x^{a}$. o recomenda fazer algum serviço $p^{a}$ achar hum vieiro". ${ }^{76}$

No dia 10 de Fevereiro de 1812, Eschwege declara sua impressão em que "a respeito do Cobalto tem o Camera todos os meios na mão $p^{a}$. poder achar alguma maior abundancia, e he bom q' V. Ex $x^{a}$ o o escreva a respeito disso, eu o indicarei os lugares mais exactos onde 
o Couto o tem achado". ${ }^{77}$ Aparentemente, o empenho de Eschwege e Câmara em encontrar o cobalto era devido a uma cobrança direta da Corte Portuguesa que incumbira a esses dois engenheiros como uma de suas principais metas. No entanto, o segundo deixa clara suas queixas a Vieira Couto, impondo-lhe críticas ferozes:

Ali (em Tijuco) verei se descubro o para mim tão problemático Cobauto do Dor. Couto, para enviar a V. Exa., como me pede; digo problemático, por que não so eu o não tenho axado, como tão bem Eschwege buscando o em lugares, que elle determinou; e sempre sera pa mim problemático e duvidozo tudo o que dicer hum homem que eu já conheci huma, e muitas vezes falsso: quem manda ao Ministerio Mineraes de Cobre d'Alemanha dizendo que pertencem a este Paiz: quem manda botoens d'ensaio de Cobre ao lado de Mineraes de Ferro, de que dizia telos tirado, não seria capaz de d'aprezentar a V. Exa. amostras de Cobauto (sic.), de qualquer parte onde o haja, dizendo serem de Tijuco? Seja embora malvada a minha Dialetica, mas ella he huma, e consequente. ${ }^{78}$

Nas palavras do Intendente, as sérias acusações de falsidade de envio de amostras e de análises químicas talvez sejam corroboradas com outros pontos que serão analisados em breve. Ainda vale pontuar que Eschwege menciona mais uma vez em seu livro que teria sido Vieira Couto o descobridor do cobalto em Minas cujas amostras enviadas em 1810 podiam se tratar de "exemplares de cobalto ferroso, de cor negra, que se apresentava, juntamente com o quartzo, num xisto ferruginoso". ${ }^{79}$ Ele destaca ainda que as localidades indicadas por Couto ao longo de Minas ou nos entornos de Tijuco não foram encontradas "pois o Dr, Couto procurou ocultá-las". Eschwege ainda descobriu o cobalto em companhia do manganês em fendas nos xistos ferruginosos na forma de "brilhantes cobaltites" ou em forma de "cobalto terroso, negro". 80

Antes mesmo de tais desencontros entre naturalistas terem ocorrido, Couto foi representado junto ao governo da Capitania de Minas Gerais através de um "Requerimento de José Vieira Couto sobre a concessão de regalias e recompensa pela descoberta de metal", documento disponível no acervo do Arquivo Público Mineiro e datado de 12 de Setembro de $1810 .{ }^{81} \mathrm{O}$ tijucano é apresentado no documento como o:

Naturalista encarregado por Ordem de V. A. R. dos exames, indagaçõens Mineralogicas desta Capitania de Minas Gerais, há treze annos tem feito a V. A. R. os serviços seguinte. Antes dele Naturalista ser encarregado destes acima ditos exames, nada sabião os Portugueses da existencia de outros metaes, além do Oiro, ou ao menos erão suas ideias a esse respeito todas vagas, incertas. Elle primeiro as fixou mostrando numerosas, e riquíssimas Minas de ferro, apreciando-as cada huma, e indicando suas diversas riquezas por Ensaios; Minas estas dignas de muito maior peso que as mesmas de oiro, Diamantes: mostra o raríssimo e precioso metal a Platina, o Cobre, o Chumbo, a prata contida neste Chumbo com conta, e utilidade, o Bismutho, o Zinco, o Sitano (Estanho), o Manganezio, o Cobalto, metaes estes trez últimos, utilíssimos nas pinturas dos esmaltes.

Frente a este serviço, "rezulttado de ásperos trabalhos, fadigas, e amiudados riscos de vida" consta no documento o aparentemente frustrado pedido de recompensas e regalias de ser elevado a Coronel da Tropa Viva com soldo completo além de sua condecoração com o Hábito de Cristo, conforme indicações feitas pelo governador da Capitania. Ao que tudo indica, tais "graças" não foram concedidas pois, de acordo com o que se indica em seu necrólogo, datado de 13 de Novembro de 1827 e publicado na revista Astréa:

Finalizava em Coimbra os seus estudos em 1777, foi logo chamado para o serviço Nacional á instâncias do Doutor Vandeli, e do immortal Linêo, e escolhido para viajar as Colônias Portuguesas: huma grave infermidade porém cortou o fio d'esta carreira, á que dava começo em seus verdes annos. Restabelecido que foi, viajou parte da Europa; e em Leide doctorando-se em Medicina voltou á sua Patria, que achou, como a tinha deixado, inculta, e em huma total ignorância gemendo debaixo da virga férrea dos Intendentes dos diamantes... Os trabalhos de Couto, destituídos de recommendação alguma, desafiarão uma Carta Regia em louvor aos seus serviços dizendo - Que ficava na sua Real aceitação e lembrança, para o augmentar grandemente; $e$ que no entanto o Governador e Capitão General proposesse o premio, que se lhe deveria dar-. Este até hoje se espera, emquanto a existencia de Couto foi sempre tão occupada no serviço publico, quanto amargorada á vista da ingratidão do Governo a seu respeito; ${ }^{82}$

José Vieira Couto morreu em 11 de Setembro de 1827 em sua fazenda, a Ermida do Gavião no Tijuco onde descansam suas cinzas, não se conhecendo alguma outra gratificação que lhe tenha sido dada por seus trabalhos em mineralogia. Certamente os frequentes erros em suas análises e a provável falsificação dos dados de suas análises tenham contribuído para que outras demandas naturalistas ou mesmo prêmios a ele não fossem mais concedidos.

Não foram encontrados outros documentos que relacionassem a descoberta ou a extração de minerais de cobalto na capitania de Minas Gerais que pudessem dar mais pistas por parte de mineralogistas ou naturalistas do século XIX.

\section{CONSIDERAÇÕES FINAIS}

Na busca por novos recursos, é bem provável que o conhecimento sobre mineralogia não bastasse ou ainda, quando esse conhecimento sobrepujava ao que era conhecido na época, que pudesse ser utilizado como arma na busca de benefícios próprios por meio de alguns naturalistas. Em relação ao cobre, podemos supor (por causa da ausência de registros atuais de cobre nativo ou mesmo de seus minerais nas regiões descritas) que os irmãos Maciel podem ter cometido erros em suas análises e terem tomado como minério de cobre os minerais que abundam em ferro e manganês da região de Ouro Preto. Isso porque, em Minas Gerais, são conhecidas apenas no município de Fortaleza de Minas (sudoeste do estado) jazidas com interesse econômico, em que os minerais têm teor de $0,05 \%$ de cobalto e teores ainda mais inferiores de cobre. ${ }^{83}$

É provável ainda que esse mesmo equívoco pode ter ocorrido com o outro naturalista citado no início da carta, José Vieira Couto, responsável por pesquisas minerais, que também indicou a presença de cobre nas suas diversas viagens de pesquisa a serviço do governo após ter indicado que os mesmos minerais se tratavam de minérios de ferro. Outra correção leva a afirmar que a capitania de Minas Gerais abundava em minérios de cobalto, muito provavelmente na tentativa de corrigir ou mascarar erros de suas memórias anteriores que logo após não são percebidas no livro que seria editado com seu nome. Fato importante sobre Vieira Couto é que ele nitidamente buscava para si próprio e para seus irmãos privilégios e cargos, depois de terem sido envolvidos nos movimentos da Inconfidência Mineira ${ }^{84} \mathrm{e}$ perseguidos pela Inquisição portuguesa, no fim do século XVIII, ${ }^{85}$ por causa de seus atos e ações heréticas e envolvimento na Maçonaria. 
Por outro lado, é à base de conhecimentos dados à luz pelas viagens mineralógicas de Vieira Couto que o Barão de Eschwege e Jean Monlevade navegavam ao examinar com mais conhecimentos, apesar de que, mesmo estando a cargo de serviços à capitania ou à província, levantavam suspeitas por não serem brasileiros.

\section{AGRADECIMENTOS}

Os autores agradecem a todos os responsáveis pelo 'Programa de Pós-Graduação em Química' e 'Departamento de Química da UFMG', em especial ao amigo Luiz Cláudio Barbosa. Agradecemos ainda aos membros do 'Opilião - Grupo de Pesquisas Espeleológicas' - Marcos Moreira e Débora Almeida - pelo suporte constante em atividades em campo e ajuda na confecção de mapas.

\section{REFERÊNCIAS BIBLIOGRÁFICAS}

1. Alexander, W.; Street, A.; Metals in the service of Man, $9^{\text {th }}$ ed., Penguin Books: London, 1989.

2. Rodrigues, M. A.; Silva P. P.; Guerra, W.; Quim. Nova Esc. 2012, 34 , 161.

3. Brasil; Cobre, Balanço Mineral Brasileiro, Departamento Nacional de Produção Mineral (DNPM): Brasília, 2001.

4. Brasil; Anuário Mineral Brasileiro: Principais Substâncias Metálicas, Departamento Nacional de Produção Mineral (DNPM): Brasília, 2018.

5. Arquivo Histórico Ultramarino (AHU); AHU-ACL-CU-017, Cx. 1, D. 15. Conselho Ultramarino, Brasil - Avulsos. Rio Janeiro. 1619.

6. http://triplov.com/estela_guedes/gaio_metodo/index.htm, acessada em novembro de 2021.

7. Idem

8. Arquivo Histórico Ultramarino (AHU); AHU-ACL-CU-015, Cx. 117, D. 8986. Conselho Ultramarino, Brasil - Pernambuco. 1774.

9. Arquivo Histórico Ultramarino (AHU); AHU-CU-005-01, Cx. 58, D. 11170-11171. Conselho Ultramarino, Brasil - Bahia. 1783.

10. Arquivo Histórico Ultramarino (AHU); AHU-CU-005-01, Cx. 66, D. 12564. Conselho Ultramarino, Brasil - Bahia. 1787.

11. Carta Régia de 1799. In: Revista Trimensal de História e Geographia. Tomo Quarto, $2^{\mathrm{a}}$ ed. Typ. de João Ignácio da Silva: Rio de Janeiro, 1863.

12. Mikesell, R. F.; The World Copper Industry, RFF Press: NY/London, 2017

13. Mendonça, M. C.; O intendente Câmara, Companhia Editora Nacional: São Paulo, 1958

14. Brasil; Autos de Devassa da Inconfidência Mineira, Vol. 8, Câmara dos Deputados, Imprensa Oficial de Minas Gerais: Brasília - Belo Horizonte, 1978.

15. Araújo, R. J.; Filgueiras, C. A. L.; Quim. Nova 2017, 40, 602.

16. Lopes, F. A.; Álvares Maciel no degredo de Angola, Departamento de Imprensa Oficial - MEC: Rio de Janeiro, 1958

17. Arquivo Público Mineiro (APM); CC - Cx. 78 - 20099. S/L - Sem data Caixa: 78; Rolo: 525

18. http://www.cmd.unb.br, acessada em agosto de 2018 (obs.: atualmente, 2021, fora do ar).

19. Arquivo Histórico Ultramarino (AHU); CMD-AHU-ACL-N-Minas Gerais Cx. 156. D. 28. C. 12028. Vila Rica, 1801. ${ }^{\circ}$ Catálogo: 11709

20. Arquivo nacional do Rio de Janeiro (ANRJ), códice 807, vol. 5, fls. 246-7 apud da Silva, Clarete Paranhos; $O$ desvendar do grande livro da natureza: um estudo da obra do mineralogista José Vieira Couto, 1798-1805. Annablume: São Paulo, 1999.

21. Arquivo Histórico Ultramarino (AHU); CMD-AHU-ACL-N-Minas Gerais Cx. 145. D. 12. C. 11105. Vila Rica, 1801. N Catálogo: 10948

22. Pereira, M. M.; Temporalidades. 2016, 8, 522.

23. Couto, J. V.; Manuscrito: Memória escrita por José Vieira Couto sobre a Capitania das Minas, seu território, clima e produções metálicas...
Tijuco, 1799. In: CMD-AHU-ACL-N-Minas Gerais. No Catálogo: 11058

24. Couto, J. V.; Memória sobre as Minas da Capitania de Minas Gerais: seu território, clima, e producções metallicas. RIHGB, (Tomo XI, 1848) Vol. Supl., Tomo Quarto, Segunda Série. Imprensa Nacional: Rio de Janeiro. 1891.

25. Couto, J. V.; Memória sobre as Minas da Capitania de Minas Gerais: seu território, clima e produções metálicas. Furtado, J. F. (org). Fundação Joao Pinheiro: Belo Horizonte. 1994

26. Idem, Manuscrito: Memória escrita por José Vieira Couto. fl. 11.

27. Arquivo Histórico Ultramarino (AHU); CMD-AHU-ACL-N-Minas Gerais Cx. 147. D. 2. C. 11327. Tijuco, 1799. $\mathrm{N}^{\circ}$ Catálogo: 11059

28. Linne, C.; A general system of Nature, through the three grand Kingdons of animals, vegetables, and mineral... Mineral Kingdom, V. 7. Lackington, Allen, And. Co.: Londres, 1806.

29. Idem. Arquivo Histórico Ultramarino (AHU); CMD-AHU-ACL-NMinas Gerais Cx. 147. D. 2. C. 11327. Tijuco, 1799. No Catálogo: 11059, fl. 5.

30. Prain, R.; Copper: the anatomy of an industry Mining. Journal Books Limited: London. 1975. Apud Tungate, S. Matthew Boulton and the Soho Mint: Copper to customer. Tese - College of Arts and Law: Birmingham, 2010

31. Arquivo Histórico Ultramarino (AHU); CMD-AHU-ACL-N-Minas Gerais Cx. 149. D. 50. C. 11397. Vila Rica, 1799. № Catálogo: 11213.

32. Arquivo Público Mineiro (APM); CC-CX. 149, D. 21437. Vila Rica, 22 de agosto de 1799.

33. Filgueiras, C. A. L.; Origens da química no Brasil, Editora UNICAMP: Campinas. 2015.

34. http://bndigital.bn.gov.br/projetos/ alexandre/historico.htm, acessada em agosto de 2018 (obs.: atualmente, 2021, fora do ar).

35. Arquivo Histórico Ultramarino (AHU); AHU-ACL-N-Minas Gerais. Cx 149, D, 172, C. 11418. Jardim Botânico, 24 de setembro de 1799. $\mathrm{N}^{\circ}$ Catálogo: 11235

36. Arquivo Histórico Ultramarino (AHU); Minas Gerais Cx. 149. D. 73. C. 11408. Lisboa, 1799. fl. 2

37. Arquivo Histórico Ultramarino (AHU); Minas Gerais Cx. 145. D. 22. C. 11140. Lisboa, 1798. fl. 10.

38. Calógeras, P.; As minas do Brasil e sua Legislação. sd.

39. Couto, J. V.; Memória sobre as minas da Capitania de Minas Geraes, suas descripções, ensaios, e domicílio próprio; Á maneira de um itinerário com um appendice sobre a Nova Lorena Diamantina, sua descripção, suas producções mineralógicas, e utilidades que d'este paiz possam resultar ao Estado. Escripta em 1801. IHGB - Laemmert: Rio de Janeiro, 1842.

40. Idem.

41. Idem.

42. Faria, L. E. Filgueiras, C. A. F.; Quim. Nova 2019, 42, 105.

43. Idem, Couto, J. V. Memória sobre as minas da Capitania de Minas Geraes.

44. Eram no total trinta e quatro amostras e os cálculos foram feitos através das notas de Vieira Couto que indicam que suas análises foram feitas tomando um teor em libras de cobre no minério por "dois quintaes fictícios". Nosso cálculo só levou em consideração as indicações em que ele apresenta ter obtido apenas cobre puro - ou "cobre-roseta", liga porosa e quebradiça de ligas de cobre impuro - e não "cobre negro", que se imagina ser óxido de cobre II, CuO.

45. Silva, C. P.; O desvendar do grande livro da natureza, um estudo da obra do mineralogista José Vieira Couto, 1798-1805. Annablume: São Paulo. 2002.

46. Couto, J. V.; Memória sobre as nitrateiras naturaes e artificiaes de Monte Rorigo na Capitania de Minas Gerais

47. Couto, J. V.; Memória sobre as salitreiras naturaes de Monte Rorigo: maneira de as auxiliar por meio das artificaes; refinaria do nitrato de potassa, ou salitre 
48. Arquivo Histórico Ultramarino (AHU); CX. 182, D. 53, C. 13451. Coimbra, 02 de Dezembro de 1806.

49. Idem, fl. 1

50. Burton, 5. Explorations of the highlands of the Brazil, Vol. 1, Tinsley Brothers: London, 1869.

51. Idem.

52. Arquivo Distrital de Braga (ADB); Carta de Guilherme, Barão de Eschwege. PT/UM-ADB/FAM/FAA-AAA/000623, 09 de Agosto de 1811

53. ht tp://acervo.redememoria.bn.br/redeMemoria/ handle/123456789/285424, acessada em agosto de 2018 (obs.: atualmente, 2021, fora do ar).

54. Arquivo Público Mineiro (APM); CC-CX. 36, D. 30071. Vila Rica, 05 de Janeiro de 1812

55. Eschwege, W. L.; Pluto Brasiliensis.

56. Índice de inventários da Comarca de Mariana; Vargas, L. S., org.; Cartório de $1^{\circ}$ Ofício: Mariana. 2008

57. Idem Eschwege, W. L.; Pluto Brasiliensis. (notas explicativas).

58. Diário do Imperador D. Pedro II (1840-1891); Bediaga, B., org.; CDROM PEDRO II, vol. 24. Petrópolis: Museu Imperial, 1999.

59. Durão, J. S. R.; Caramurú. Poema épico do descubrimento da Bahia, $2^{\mathrm{a}}$ ed., Impr. Nacional: Lisboa. 1836.

60. Idem, Eschwege, W. L.; Pluto Brasiliensis.

61. Camara, J. S. B.; Memória mineralogica do terreno mineiro da Comarca de Sabará. Revista do Archivo Público Mineiro. Imprensa Official de Minas Geraes: Ouro Preto, $1897 I$.

62. Idem

63. Johanson, P.; Cobalt. Understanding the Elements of Periodic Table, The Rosen Publishing Group: New York. 2008.

64. Weeks, M. E.; Discovery of Elements, $6^{\text {th }}$ ed., J. Chem. Education: Easton. 1956.

65. Gauthier, G.; Deliens, M.; The Mineralogical Record. 1999, 30, 255.

66. https://www.cobaltinstitute.org/about-cobalt/the-cobalt-value-chain/ cobalt-use, acessada em novembro de 2021.

67. Brasil; Sumário Mineral de 2014, Cobalto, DNPM: Brasília. 2014
68. Op. cit. Arquivo Histórico Ultramarino (AHU); CMD-AHU-ACL-NMinas Gerais Cx. 156. D. 28. C. 12028. Vila Rica, 1801. № Catálogo: 11709

69. Op. cit. Arquivo Histórico Ultramarino (AHU); CX. 182, D. 53, C. 13451. Coimbra, 02 de dezembro de 1806

70. Idem, fl. 10.

71. Medeiros, M. A. QNEsc 2013, 35, 220.

72. Op. cit. Arquivo Histórico Ultramarino (AHU); CX. 182, D. 53, C. 13451. Coimbra, 02 de Dezembro de 1806, fl. 13.

73. Idem, fl. 1

74. Idem, ibidem.

75. Arquivo Distrital de Braga (ADB); PT/UM-ADB/FAM/FAAAAA/001361, 27 de abril de 1811.

76. Arquivo Distrital de Braga (ADB); PT/UM-ADB/FAM/FAAAAA/000624, 20 de nNovembro de 1811.

77. Arquivo Distrital de Braga (ADB); PT/UM-ADB/FAM/FAAAAA/000627, 10 de fevereiro de 1812.

78. Arquivo Distrital de Braga (ADB); PT/UM-ADB/FAM/FAAAAA/001363, 13 de janeiro de 1811

79. Idem, Eschwege, W. L. Pluto Brasiliensis...

80. Idem, ibidem.

81. Arquivo Público Mineiro (APM); CC - CX. 95 - 20383. Datas-limite: $15 / 10 / 1800-15 / 10 / 1810$

82. Jornal Astréa (necrologia); ed. $n^{\circ} 210$. Rio de Janeiro, 13 de Novembro de 1827.

83. http://recursomineralmg.codemge.com.br/substancias-minerais/ niquel/\#dep\%C3\%B3sito-de-ni-cu-co-au-pge-fortaleza-de-minas, acessada em novembro de 2021.

84. Furtado, J.; Sedição, heresia e rebelião nos trópicos: A biblioteca do naturalista José Vieira Couto. In: Dutra, E. F.; Mollier, J. (org.). Política, Nação e Edição; o lugar dos impressos na construção da vida política: Brasil, Europa e Américas nos séculos XVIII-XX, Anablume: São Paulo, 2006

85. Rocha, I. T. C.; Oficina do Historiador 2014, 7, 19. 